\title{
THE COMPLEXITIES OF PERCEIVED AND EMPIRICAL REALITY ON ENVIRONMENTAL PERFORMANCE: INDUSTRIAL CASE STUDIES IN CHINA, LITHUANIA AND POLAND
}

\author{
John H. S. Craig ${ }^{1}$, Mark Lemon ${ }^{2}$ \\ ${ }^{1}$ Girac (Consultants) Limited, The Wilderness, Old Forge Lane, Preston Capes, NN11 3TD, UK \\ ${ }^{2}$ Institute of Energy and Sustainable Development, De Montfort University, Leicester, LE1 9BH, UK \\ E-mail: 1john.craig@girac.co.uk
}

Submitted 22 Apr. 2009 accepted 16 Oct. 2009

\begin{abstract}
The culture of a company is often cited as the basis for how well that company performs both economically and environmentally. This can also lead to the development and adoption of generic management approaches that fail to adequately acknowledge the existence of multiple cultures within the organization or the potential disjuncture between how performance is perceived by personnel and any attempts to measure that performance in an 'objective' manner. This failure to respond to the complexity of multiple cultures and perceived performance and the instigation of over-arching management systems can discourage constructive dissent and hinder the related capacity for innovation and improvement. This paper draws upon research into the level of congruence between perceived and objective measures of environmental performance in thirteen factories from the heavy industrial sector in China and Eastern Europe. It presents findings that suggest managerial interactions, both laterally and vertically, are mediated by socio-cultural networks within and between family, community and workplace, resulting in a high level of unbounded complexity that influences the alignment between perceived and objective environmental realities.
\end{abstract}

Keywords: complexity, culture, realities, language, hierarchy.

\section{Introduction}

Hodge and Coronado (2007) identify a paradox in the language of business and organizational science. On the one hand there is enthusiastic discourse about the value of continuous change and the opportunity that this offers for those who can live with the chaos; elsewhere there is a pressure to ensure stability and the orderly management of change. Central to this paradox are the existence of multiple cultures within an organization (Mars 1994), compromising any attempts to generate a homogeneous identity and set of working practices, and creating a corresponding disjuncture between perceived and objective performance (Craig and Lemon 2008). This paper will explore the complexity that emerges from these phenomena as they are manifest through the environmental performance of thirteen Chinese and Eastern European factories engaged in the heavy industrial sector.

The paper does not follow a traditional structure with data and analysis following a summary of the key literatures. Rather, and in keeping with the complexity of the research findings to which it refers, the paper will introduce relevant explanatory literature as the findings from the case studies emerge. This is consistent with the need to combine inductive and deductive scientific approaches within an integrative methodology that reflects the need to explore both the perceptual evaluation of environmental performance and that which can be empirically measured in accordance with various objective benchmarks e.g. ISO 14001. The paper will commence with the background to the research and an explanation of the methodology employed, initially in Poland and subsequently in China and Lithuania. The case study factories will then be described and a summary of the attributes of factory based complexity presented before a more detailed discussion of the key findings that help to explain that complexity and the resultant disparity between the objective and perceived reality of environmental performance.

\section{Methodology and background to the study}

Initial research was undertaken in five Polish factories 1998 and was grounded in the hypothesis that, following 1993 and the collapse of the communist regime; educational resources concerning the environment would be limited leading to a lack of control over environmental degradation. This hypothesis proved to be an illusion. It was found that whereas sufficient knowledge was available from the universities a complex array of organizational phenomena in the factories constrained the introduction and dissemination of environmental knowledge. Such that poor decisions were being made in the context of a myriad of incoherent personal realities within a fear-bounded authoritarian management culture (Craig \& Lemon 2004).

A second phase of action-centered research commenced in 2001 (Craig \& Lemon 2005); this encompassed an additional seven factories in China and one in Lithuania (included as a control against the Polish facto- 
ries in a comparison of Soviet dominated bureaucracies) in order to both delve deeper into the phenomena identified in the earlier research and to determine any differences between national and management cultures. This research identified further influential phenomena, including those related to gender, age and position in the management hierarchy, but mainly to the differences between benchmarked (empirical) and imaginary (perceptual) realities (Hume 1739; Noonan 1999) in heavy industrial production and environmental degradation.

The case study factories were large, on sites of up to fifty hectares, and within a single heavy, electrical engineering industrial sector. In China they were built with up to five stories but the total floor area of each was still less than those in Lithuania and Poland which occupied largely single storey buildings. In China the seven study factories were located in various regions, Dong Guan Province, Shanghai Region and Hong Kong. As the factories were often a long way from their home towns, the general workforce in China tended to be housed in factory dormitories and it was also usual for the managers to live in single rooms in management dormitories at the factory site. The top manager on each site was always foreign Chinese, from countries such as Singapore, Taiwan and Hong Kong, and with Western capitalist management experience. The lower levels of management were nearly always mainland Chinese with a management culture drawn from the communist era and based on the Confucian bureaucratic ethos (Fernandez 2004; Tsui et al. 2004).

The five Polish factories were located across the country; all were close to large towns and employed a predominantly local workforce. Some of the more senior managers, who were moved frequently between factories in the same group of companies, lived in rented accommodation near the factory while maintaining their homes in distant locations. The top manager on each site was always Polish and with little or no training in, or knowledge of, Western management techniques. As with China, there was substantial bureaucracy, a command and control ethos and a fear and punishment culture. The single Lithuanian factory surveyed served as a control against the Polish factories. Both countries were ruled according to Russian dictat for some fifty years and the organizational bureaucracies should match in any comparison. Any differences would highlight different sociocultural mechanisms in play.

The workforce levels in Poland and Lithuania were mostly higher, but so was the range of products; in parallel with this the Polish workforce was better trained and did sometimes, despite hierarchical restraints, use initiative. This difference extended to the environment although both sets of factories tended to be content with staying below the legal limits (e.g. for groundwater and chemical control) rather than improving; in particular there remain serious risks of large scale environmental outrages due to the storage methods for, and handling of, toxic oils and chemicals.

The factories in both China and Eastern Europe were subject to significant change; China with rapid growth leading to stress in managerial ranks and Poland with a massive workforce reduction in order to cut costs and compete on price with EU companies. This also caused considerable stress on managers as it involved high levels of redundancy. The triangulated methodology adopted for the study consisted of four parts with each data stream providing a check on the others:

-reality benchmarks (rbm's) were derived by an environmental expert derived from detailed expert observations of factory impacts on the environment; the environment and production processes;

- a strength of feeling (SOF) questionnaire was administered to over two hundred managers in order to elicit how aspects of environmental performance were perceived;

- semi-structured interviews were carried out with the senior manager at each of the thirteen factories;

-informal discussions were undertaken with other managers and analyzed alongside the data derived from workshops that were organized in each factory to discuss the interim research results and obtain feedback from management and supervisory staff.

The purpose of the overall methodology (see Craig \& Lemon 2008) was to determine the socio-cultural group patterning within each factory; this would provide a comparative framework for understanding the dynamics leading to knowledge transfer and environmental decision making (Merton 1967; Frost 1991; Zey 2001). A prime factor in these dynamics was the gaps between the practical truth of production and related environmental impacts, as determined by the expert derived benchmarks, and the perceptions of the managers about those impacts and how they defined environmental performance.

\section{Mapping factory interactions and network complexity}

\subsection{An ideational framework}

It is proposed by Merton (1967) and Archer (1996) that ideas cannot be subject to mutation in the sense that, if there is a logically coherent culture (LCC) which is logical, generated from top management and homogeneous, throughout a company, then there will be no elision of, or addition to, that cultural idea, as logic is immutable. This proposal is convenient for research use in the management cultures which are of the iron cage variety (Weber 1904), i.e. strongly hierarchical; however the uncertainty that arises with the existence of multiple (sub-) cultures within an organization, and the associated perceptions, mean that management according to logical coherence can be problematic.

There are also linguistic problems which cause mutations of understanding (Glen et al. 2003; Holmes 2001; Cobley 2001) as every individual has his or her own lexicon and puts a tacit interpretation on any communications from above or below in the management ranks (see also Lubit 2001). This can be compounded in the middle ranks (in the management chain) where the manager may 


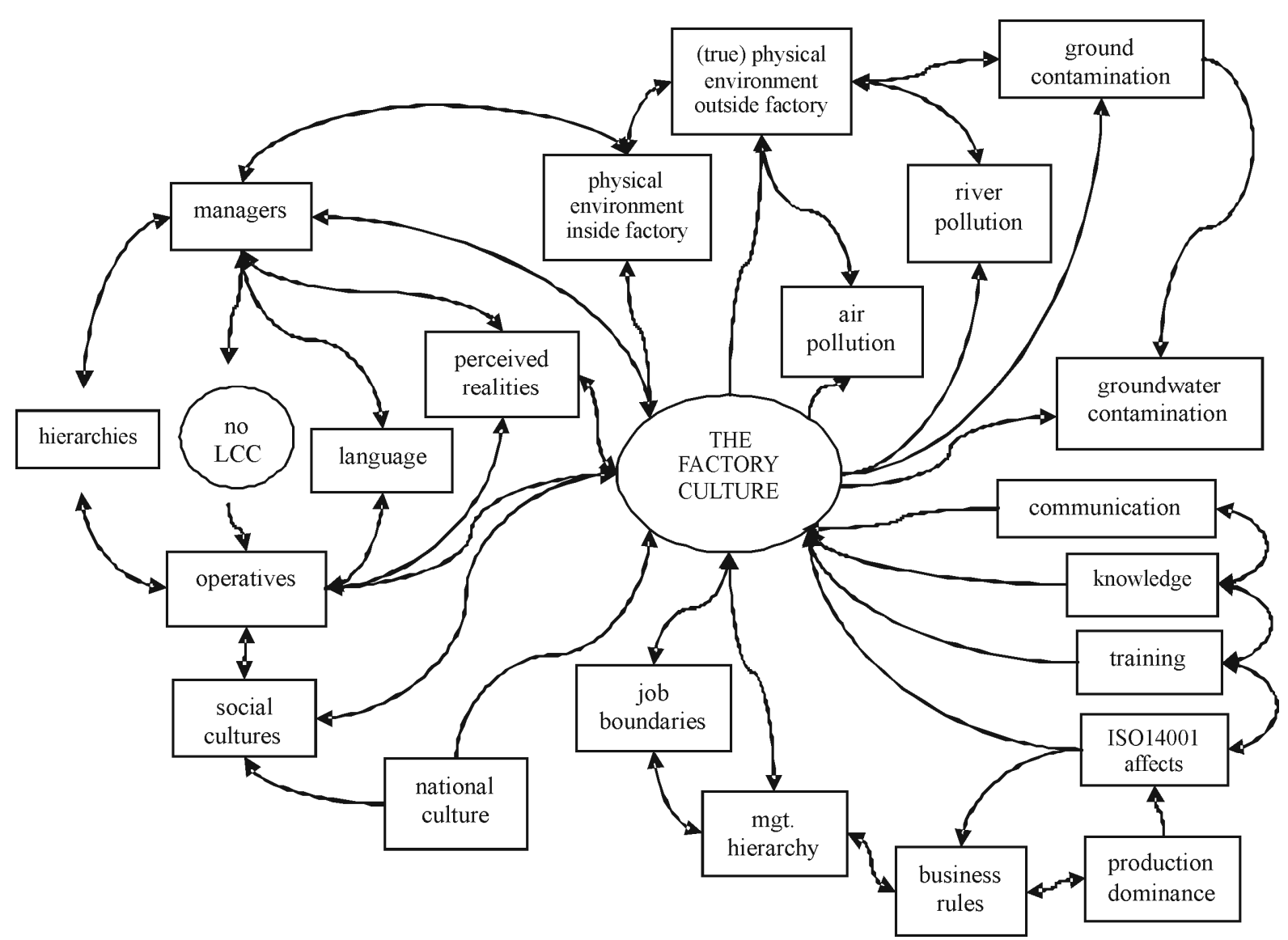

Fig. 1. Mapping of some of the interactive variables (taken from the research data)

re-interpret any communication to suit both the person above and the person below in order to maintain a noncontentious working relationship with both. The sociocultural situation becomes more complex when there is no communication from senior management beyond the transmission of orders; however it is possible under certain 'sub'-cultural conditions that interpretations of the order can be malleable so as to create space (Mars 1994) for that middle manager.

\subsection{Organization dynamics and process}

In Fig. 1, some of the complexities of interaction between managers and the workforce, derived from the case studies, are mapped together with those between levels of management and some of the environmental impacts resulting from the factory operations which management should be monitoring and controlling. One important aspect of this interaction is the dominance of production which is perceived by many managers as the most important facet of operations - profit depends on output is the unsung mantra. Hence, the environmental requirements of certification to ISO14001, or an acceptance of the need not to degrade the environment, are mediated by not prejudicing production on account of environmental remediation.

On the left-hand side of Fig. 1 there are the interactions between the managers and the operatives which are affected by organizational hierarchies, the language of communication (Holmes 2001; Ramsey 2004), the lack of an overriding management mission or culture (Archer
1996) which could mediate that language and individual realities (perceptions) which might or might not affect the communication and subsequent action.

Towards the bottom of the figure are the main aspects that affect the factory and inform internal culture, the national culture, the management hierarchies and job boundaries and the business rules which reinforce the dominance of production. To the right-hand side of the figure are the topics which affect the expertise of individuals in the organization, the communication ethos, the communicated (explicit) knowledge and training and the ambiguity of the demands of certification to ISO14001.

At the top of the figure, and towards the right, there are some of the primary elements of environmental degradation which were subject to the generation of perceptions largely independent of empirical evidence on the ground (Craig and Lemon 2004, 2005).

Table 1 summarizes the most important variables and grades the strength of their relationship based on over two hundred interviews with managers at all levels from board directors to supervisors. The perceived and empirical realities were taken from the survey data broken down by each management level and the extent of the gap between the two is taken as an indicator of the level of impact on decisions.

As an example, the absence of a logically coherent culture was shown, in the research, to have little effect (L) in relation to social class which, in the countries concerned, was taken as professional, technically or commercial qualified and unqualified technical or commercial. However, 
Table 1. Strength of relationship between researched variables ( $\mathrm{H}$ - high; $\mathrm{M}$ - medium; $\mathrm{L}-$ low; $\mathrm{N}$ - no effect)

\begin{tabular}{l|l|l|l|l|l|l|l|l}
\hline & 1 & 2 & 3 & 4 & 5 & 6 & 7 & 8 \\
\hline 1 no LCC & & $\mathrm{L}$ & $\mathrm{H}$ & $\mathrm{H}$ & $\mathrm{H}$ & $\mathrm{H}$ & $\mathrm{H}$ & $\mathrm{H}$ \\
\hline 2 social class & $\mathrm{L}$ & & $\mathrm{H}$ & $\mathrm{N}$ & $\mathrm{M}$ & $\mathrm{H}$ & $\mathrm{H}$ & $\mathrm{M}$ \\
\hline 3 language & $\mathrm{H}$ & $\mathrm{H}$ & & $\mathrm{H}$ & $\mathrm{H}$ & $\mathrm{H}$ & $\mathrm{M}$ & $\mathrm{M}$ \\
\hline 4 empirical reality & $\mathrm{H}$ & $\mathrm{H}$ & $\mathrm{H}$ & & $\mathrm{L}$ & $\mathrm{H}$ & $\mathrm{H}$ & $\mathrm{L}$ \\
\hline 5 perceived reality & $\mathrm{H}$ & $\mathrm{H}$ & $\mathrm{H}$ & $\mathrm{L}$ & & $\mathrm{H}$ & $\mathrm{H}$ & $\mathrm{H}$ \\
\hline 6 mgt hierarchy & $\mathrm{H}$ & $\mathrm{H}$ & $\mathrm{H}$ & $\mathrm{L}$ & $\mathrm{L}$ & & $\mathrm{H}$ & $\mathrm{M}$ \\
\hline 7 decisions & $\mathrm{H}$ & $\mathrm{M}$ & $\mathrm{M}$ & $\mathrm{L}$ & $\mathrm{H}$ & $\mathrm{H}$ & $\mathrm{H}$ & $\mathrm{M}$ \\
\hline 8 job boundaries & $\mathrm{H}$ & $\mathrm{M}$ & $\mathrm{N}$ & $\mathrm{M}$ & $\mathrm{L}$ & $\mathrm{H}$ & & $\mathrm{N}$ \\
\hline 9 core peer groups & $\mathrm{H}$ & $\mathrm{L}$ & $\mathrm{L}$ & $\mathrm{N}$ & $\mathrm{H}$ & $\mathrm{L}$ & $\mathrm{L}$ & \\
\hline
\end{tabular}

the language used at management interfaces between people with different social backgrounds, was exhibited as giving a high $(\mathrm{H})$ level of misunderstanding or incomprehension. The grades are subjective, but based on an interpretation of the survey results, interviews with managers and observation of communication between managers at different levels. The paper will now explore some of these interactions in more detail.

\section{Some complex effects of social class and language in the factories}

The administered survey across managerial levels in each factory indicated more fragmentation (Frost et al. 1991), i.e. different Strength of Feeling scores at different levels in a company relating to the same topic at lower levels of the management chain, One explanation for this may be the vagueness and ambiguity of language which will be dependent on education and social class and which will determine the translation of physical events into perceived impact (Shenghua 2008). The effect of the fragmentation is summarized in the table at the foot of Figs 2 .

Although there are more people in the lower management ranks, the ordinate is normalized (relative abundance) so the charts can be compared directly. Translation of physical events into perceived impact (Shenghua 2008). The effect of the fragmentation is summarized in the table at the foot of Fig. 2. Although there are more people in the lower management ranks, the ordinate is normalized (relative abundance) so the charts can be compared directly. Further, the data indicated that:

- In China, the sub-ordinate performs a task according to their understanding of what they are told;

- In Poland, the sub-ordinate massages any communication into a form congruent with their in-built or peer culture.

Both of these observations were subsequently supported in discussions with plant managers.

For the purpose of this analysis, socio-cultural groupings are defined as comprising those people with like perceptions whereas social class, on the other hand, is broadly dependent upon education and relative wealth. From the research data it was determined that the lower down the management chain the lower the social class and the more fragmented the perceptions at a given management level (see Fig. 2 in particular for Poland). Cameron and Quinn (1999) propose that individual organizations, departments, product groups, and hierar- chical levels may all have unique sub-cultures which for any topic, may change materially and temporarily, producing further complex interactions, themselves compounded by social class.

Any research into cultural dynamics as a tool for analyzing types of dysfunction in organizations must also include, even if they are covert, issues of relative dominance. Archer (1996) parades the ideas of dominant ideologies as being primarily about the ruling class (e.g. business owners or top managers) but the argument can also be taken to facilitate analysis at lower levels such as operatives (social agency) wherein the assent of the socio-cultural class or persons to be dominated (Locke
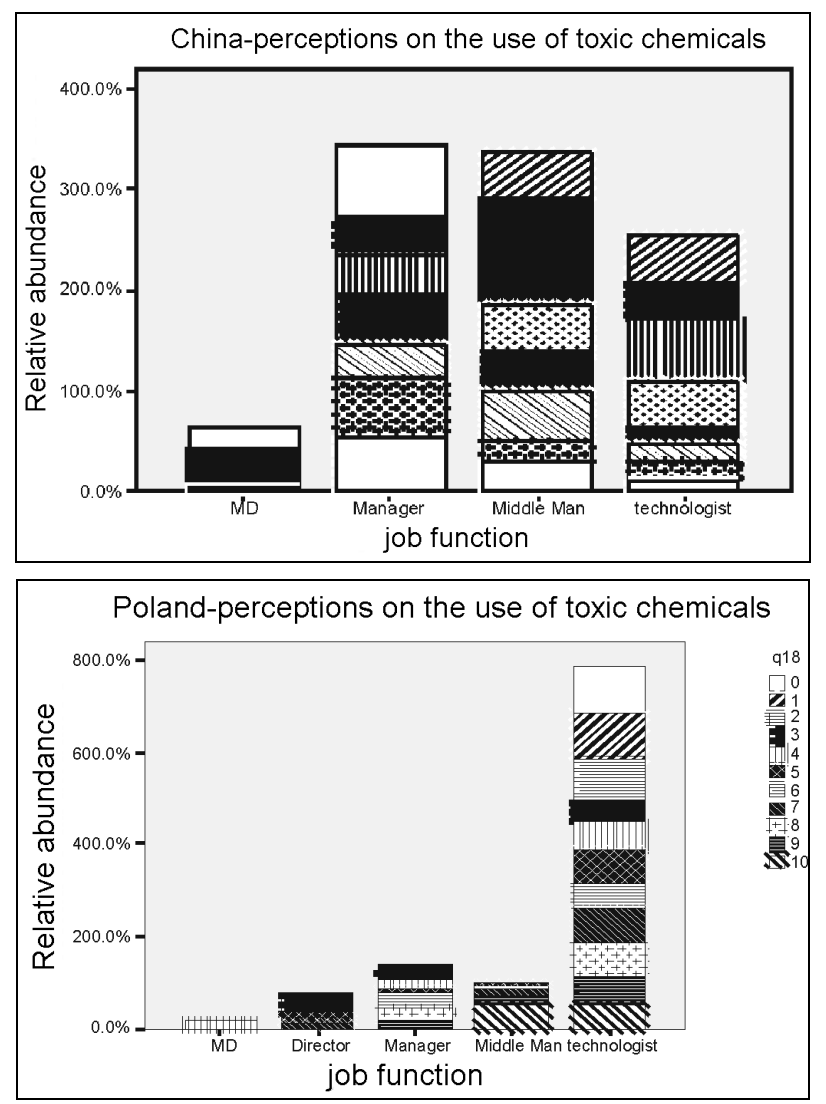

\begin{tabular}{|l|c|c|c|c|c|}
\hline & Director & MD & $\begin{array}{c}\text { Manager } \\
\text { (mgr) }\end{array}$ & $\begin{array}{c}\text { Middle } \\
\text { mgr }\end{array}$ & $\begin{array}{c}\text { Techno- } \\
\text { logist }\end{array}$ \\
\hline China & 3 & 1 & 6 & 5 & 11 \\
\hline Poland & - & 3 & 7 & 7 & 8 \\
\hline
\end{tabular}

Fig. 2. Numbers of the fragmentation of perceptions down the management chain 
$1690,1764)$ is required before dominance is exerted. Examples of where this does not happen are given in Mars (1994). Moreover, additional baggage taken into the work environment will include a language dependent upon social class and schooling, for instance, Durkheim (in Alexander 1988) avers that language codes indicate clues to social class, with the middle class having a more abstract language content and a more cosmopolitan outlook in an organic solidarity, whereas the working class tends to have different control life-interests (Dubin 1962). One interesting example of this phenomenon was observed in a Chinese factory where the senior manager was trying to understand why a lower middle manager was not obeying an instruction, issued face to face, to take some specific actions in relation to the environment - see case note 1:

\section{Case note 1: Factory $S$ in China}

The conversation between them lasted some forty minutes but it became obvious that they did not understand each other and the discussion was ended without a solution they both had individual language and realities (see also Glen et al. 2003). The top manager was a Singaporean, trained in Australia in Western management ways and language, while the middle manager was mainland Chinese with little or no knowledge of that type of imagery, language or management ethos (see also Chen et al. 2004; Chen 2001).

When coming into an organization, younger people will be beginning to move from under the dominance of the parental home and into the dominance of the industrial home (Nobbs et al. 1980), which will reinforce some perceptions, destroy others and imbue some new cultural precepts (see also Rose 1962). Hence, survey questions may elicit answers from this group which may be given from a set of person-centric perceptions which are in various states of complex temporal transition - see case note 2 .

\section{Case note 2: General}

The job of environmental managers in the Chinese factories was given to the quality managers who were young women with little factory experience and exhibited little knowledge of the formal and informal practices in production technologies, nor of the language of the organizations and the environment.

In the Polish and Lithuanian factories, three had young women in this position and three had mature women in charge, these latter having both factory experience and a better understanding of 'factory language' and the environment.

The research indicated that the transition from leaving school and progressing to a mature understanding of factory and language practice takes time and requires an adjustment of language to meet the social mores of the organization

\subsection{Language, meaning and organizational communication}

The complexity of intra-organizational communication has been extensively addressed (Shenghua 2008; Glen et al. 2003; Alvesson 2002; Holmes 2001; Cameron \& Quinn 1999; Alaasutari 1993; Zey 1992; Wierzbicka 1991; Badcock 1991; Faludi 1987; Brehmer 1986; Bellah 1973; Rose 1962).

Rose (1962) proposes that human beings use symbols such as language to stimulate action on the part of others; symbols have a learned meaning and value for those others. However, the learned meanings are not necessarily identical between managers, but rather depend on individual and complex perceptions of these meanings. These meanings are therefore themselves susceptible to error, ambiguity and complexity.

For the executive managers within the case study factories a fundamental challenge was to identify and implement the appropriate language for communicating organizational instructions across 'sub' cultural boundaries. Bellah (1973) argues that we all use the same words without giving them the same meaning; while Wierzbicka (1991) states that people remain in certain cultures, guided by certain principles which are not always shared more widely. She goes on to propose that in order to obtain human understanding (of meaning) it is necessary to find terms which belong to both parties in an interaction. In the context of organizational cultures, Cameron and Quinn (1999) suggest that these are reflected by:

.... what is valued, the dominant leadership styles, the language and symbols, the procedures and routines, and the definitions of success which make an organization unique...

Further, Glen et al. (2003), looking at social interaction, find that 'relationships are constructed and negotiated moment by moment in a 'delicate to and fro', hence the problems of meaning in language are compounded by personal relationships. This is a phenomenon noted by Badcock (1991):

Language increases the possibilities for deception and self-deception. If language permits much more detailed and extensive information, it also permits and encourages the communication of detailed mis-information.

In the discussions and survey for this research it was evident that some half-truths and massaged truths were promulgated, sometimes to generate the space mentioned by Mars (1994) and sometimes to obfuscate mistakes in decision-taking and outcomes. Likewise Benveniste (1981) proposes that people will formulate strategies to counter management practices which are perceived as threats, whereas management will pursue opposite strategies to seek to control of these practices, thereby compounding (system) errors by not understanding the real and complex socio-cultural dynamics.

Overall, language and meaning are seen as playing a very significant part in organizational dynamics and increasing complexity, exacerbated with what Shenghua (2008) sees as vagueness and ambiguity and, to a large extent, this dimension is made even more complex by person-centric realities related to job roles. These realities will affect and alter any communications and actions. 


\subsection{Socio-cultural complexities in communication}

If perceptual realities create an imaginary culture which is causing real effects, then it becomes an empirical reality with empirical effects. An example of one of these real affects can be taken from case note 3 .

Case note 3: The researcher facilitated a workshop on interactions and culture in Factory $\mathbf{C}$ in China:

Several important things came out of this workshop: Firstly, all the managers said that this was the first time that they had actually got to know the interests of their colleagues and that this allowed them to understand people better and perhaps would enable them to work together better. Secondly, they were profoundly interested in various environmental topics such as the geographical extent of their impact, including effluent to river and waste dispersal to some undetermined place. This emerged even though the company was certified to the ISO14001 environmental standard.

This applies also to socio-cultural groups where imagery may be driven by both imagined and real contexts; hence perceptions can be related to beliefs and culture even if these perceptions are based on imaginary contexts, or to a different interpretation of a physical fact as outlined by Hume (1739).

\section{Case note 4 from Chinese factory $S$ : \\ A supervisor was told that an operator had acciden- tally swallowed a quantity of acetone and emergency action was needed - should he make the operator vomit or not? As there were no local safety data sheets (SDS's), these being stored on the computer network, a crowd of managers took about five minu- tes to decide that the supervisor should look on the computer for the safety information. It took ten mi- nutes to get the correct program on line and then ano- ther five to find the SDS, unfortunately it was only present in English which no one on the factory floor understood - the operator was pronounced dead. The perceptual reality of the managers was that manage- ment had adequate control of dangerous chemicals; the empirical reality was somewhat different.}

The case note company had a set of fragmented perceptions and a culture characterized by a lack of knowledge sharing from the top management. There was a socially constructed antithesis to a logical culture, and an example of what Zey (1992) proposes, in that information can be socially constructed, and individually and differentially interpreted.

Since information is being represented within a world comprised of linguistic interpretations and perceptions, the proposals of Alasuutari (1995) also apply in that reality is also socially constructed. Holmes (2001) cites Bernstein on the lines that people with constricted language ability will also find difficulties in cognition. Hence, any communication needs to be in a form of language which will seek to touch the right triggers in an individual's conceptual and perceptual abilities (see Morgan 1989, 1998, and Paton 1996) on mental models, and
Senge (1992) on entrenched mental models related to people's personal realities).

\section{The complexity of empirical and perceived realities}

In most cases in the survey, examination of the data demonstrates that empirical and perceptual reality, concerning environmental and related aspects of production, do not correspond and can be considered as largely independent of each other. Moreover, the perceptual realities, as represented by the perceived strength of feeling scores derived from management questionnaires were also often not aligned. This lack of coherence extends to and between the factories themselves, with relatively few matching perception patterns representing context-dependent imagery in the minds of the managers and thereby multiple realities.

The survey data showed that, for eighteen out of the twenty question topics on production and the environment, the perceptions within and between each individual factory were very different and significantly fragmented. These gaps between empirical and perceptual realities, and the further gaps of understanding in communication between managers, are themselves complex and exacerbated by the avoidance of risk in the decision processes (case note 4).

Values, knowledge and motivation, among other things, can affect how and why decisions are taken. As Brehmer et al. (1986) notes, motivational tendencies are temporal and multitudinous at any one time, leading to a consideration that one cannot forecast the context of a future decision on a person's record of past decisions.

In the context of this motivation, there is also the confusion between that which pleases us in the personal environment and that which we judge with our professional eyes (Faludi 1987). Faludi goes on to say that:

In the comparative evaluation of consequences following an act: consequences may be anticipated or unanticipated, and anticipated consequences may be either sought or unsought.

The situation consists only of those objectives which have reliance in terms of the end-system of the organization, therefore consequences ...... only exist in relation to ends.

In the research reported here, even where people had the requisite knowledge for taking a good decision, a significant proportion geared those decisions to self-benefit while others talked of the dangers of having knowledge, ostensibly because the managers would get rid of the subordinate if they feared competition. Wallace et al. (1999) extend this argument (from research in IBM) noting the ambiguities in the extent to which people are oriented towards self-interest versus the orientation towards the interests of a wider group of which they are part, this being mediated by uncertainty avoidance i.e. the extent to which people seek to minimize uncertainty versus the extent to which they are tolerant of ambiguity.

It is in this context that Fig. 3 is derived. Here the crossed arrows at the top right shows a six by four set (matrix) of interactions all of which are likely to affect those emotions that will determine if there will be a reasoned response, or 


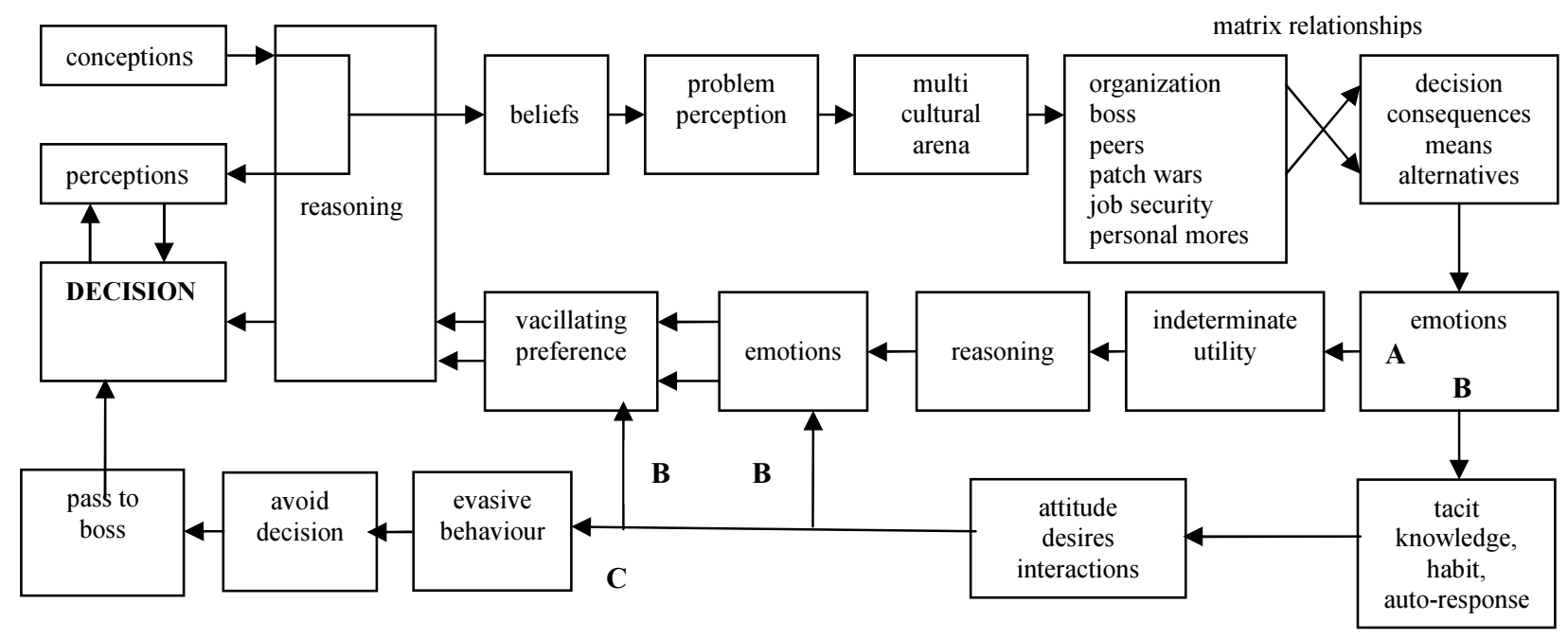

Fig. 3. Complexities in decision making (adapted from Perugini \& Bagozzi 2001; Lindsay \& Norman 1977)

a tacit response leading to a tacitly actuated decision (see also Tyska 1986). In following path $\mathrm{A}$, an indeterminate utility means that no reasoning has yet taken place as to the utility of any options from the preceding matrix and, even after reasoning, there may be vacillation occasioned by the company and personal attitudes to risk taking. Path $\mathrm{B}$ is the main option deployed in the subject factories as they all operate a punishment culture wherein risky decisions are avoided.

In this context, when the opportunity arises, decisions can be passed on to the line manager. Path $\mathrm{C}$ indicates a simple bypassing of reasoning in the decision process. This process can be so intricate that it is truly of significant complexity and is a prime example of where the bureaucratic Iron Cage of Weber (1904), deployed in all of the survey factories, fails to restrict uncertainties in behaviors and outcomes in organizations as exemplified in case note 5 .

\section{Case note 5: Senior manager in a Polish factory \\ This manager stepped outside his official job descrip- tion by taking a decision outside his remit and saved the company 30,000 Zloty. He was disciplined by the MD, had his salary frozen for the year and his six-month bonus cancelled. A prime example of the consequences of stepping outside the iron cage of beurocracy and the risk of taking decisions.}

He displays the notice from his MD declaring this punishment, framed, on his office wall.

Hence, the decision process comprises a large, and largely indeterminate, number of variables going from an individual's personal realities about many inter-related topics, through sets of choices dependent on temporal, locational and material risk options, to evasive behaviour i.e. avoiding or offsetting blame; and when the opportunity arises passing decisions on to the line manager.

\section{Case note 6: Polish factories}

In the research, all the managers and boards of directors in the Polish factories were newly appointed, parachuted from one factory to another and moved so often that they did not have the chance to determine the nature of the culture they were trying to communicate into. One parachutist Managing Director lamented his lack of understanding of the senior managers culture of lateral communication, while two of his senior managers expressed reservations about the MD's ability to communicate vertically. Private conversations with all the top managers confirmed that they recognize this problem but do not know how to tackle it. It is likely to be a cultural or hierarchical dysfunction of high complexity.

Organization structures and rule systems may, however, provide a stabilizing and integrating force (Frost et al. 1991; Burgess 1962) over and above their functional effectiveness. Cameron and Quinn (1999) reenforce this argument stating that co-ordination in a turbulent environment is most effectively facilitated through the sharing of values, beliefs and goals. While the work environment for the research during these periods was one of rapid change, Craig (2001) established that more than one culture existed within the management hierarchy which led to significant differences between what top management desired and what happened at the workeragency level (Archer 1996; Case note 6).

Case note 7 - from a private conversation with a senior manager at Polish Factory M:

"When the company was young (and small) some five years ago, it was comfortable and we all grew together and communication was easy and people were relaxed; if I asked for a decision my boss would say 'go away (and decide yourself)'. Now competences and job boundaries are narrowly defined and it is hard to find out who is responsible for some things; in the old days people were trying to do their best, never saying 'it is none of my business'. Due to the mixing (exchange) between the different factories the easy solving of problems has ended - there is less emotional involvement". 


\section{Management hierarchies and social systems}

\subsection{Structure and rule systems}

Every one of the factories had a hierarchical structure with its command and control rules and associated culture (Weber 1904 \& 1948; Lounsberry and Carberry 2005; Neilson et al. 2005). This is a little surprising to find in the mainland Chinese factories where the structures were enforced by Westernized management that might have pursued a more interactive and human-centric approach to man-management. This is partially contradicted by $\mathrm{Fu}$ et al. (2004) who states that Hong Kong based managers are more prone to pressurize, whereas mainland Chinese put more emphasis on persuasion. In the factories, where there are foreign Chinese Managing Directors and a mainland Chinese workforce, this dichotomy has not been fully resolved leading to complex interactions of perceived realities further separated by cultural differences (Chen et al. 2004).

In all the study factories there has been no evidence of top management initiated culture, beyond that of command and obey. This has been evidenced by a lack of direction and motivation amongst senior managers in Poland, while in China it appears restricted to a lack of direction. For instance, every factory has an environmental statement about how it is going to take care of the environment but the commitment is not fully translated into reality on the ground, effectively it can be classed as a façade to satisfy market-place opinion at minimum cost to production.

This lack of a management initiated culture can be seen to foster further complexities (Sperber 1996) in factory operations which have led to contingent ambiguities in practical command and obey situations. However, Burgess (1962) puts a more subtle argument in that, talking of societal process as organization, disorganization and re-organization (the equivalent of Archer's thesis, antithesis and synthesis) he states that this gives a static community or social group but that this in turn encourages revolt against the status quo, this no doubt changing the organizational dynamics.

Technical and meaningful communication with employees in all the factories had been observed as poor over many years prior to the commencement of the research, with the possible exception of orders collectively agreed as imperative. However, the general management perceptions on the quality of environmental systems are that communication is good, whereas the ISO14001 audits have highlighted significant failures in management communication and the consequential decisions and outcomes due, in may cases, to the phenomena mentioned in case note 6 . It indicates that senior and top management are not cognizant of what is really happening in the organization; a feature that is covered by Neilson et al. (2005) for passive-aggressive organizations.

Hence the management hierarchies have failed to control the rather complex socio-cultural groupings which are formed, and change temporally, dependent upon changes in the organizational environment and bureaucracies (see also Stacey 1992). The combination of a fear and punishment top-management ethos, education, language, social class and person-centric realities institute further complexities by the seemingly unintended consequence of causing rigid job boundary demarcations (see Case Note 7).

\subsection{Job boundaries}

It could be argued that the Polish workforce is better and more broadly trained and more likely to interpret commands in an innovative and constructive way "we know better what this line can do', than their Chinese counterparts - but read case note 7 which shows an example of what can go wrong. The Chinese, however, have the advantage of carrying no old technology practice or baggage. Taylor (1911) suggests that the worker has the skills and management must use these, but the impediments in China appear to be the barriers of socio-cultural discontinuity, e.g. language barriers to effective communication (due to national and industrial cultural differences between countries) occurring at management boundaries alongside less broadly based skills in production.

In the context of hierarchies, covert and overt behaviour are both deployed in the self-restriction of control (boundaries) in order to avoid responsibility. In two Chinese factories this had happened to such an extent that the top managers could not see a solution to overcoming agency, where people turn ideas into action and tend to dominate in operational areas such as the measurement of system or product parameters.

This aspect of the elision of management messages through incoherent cultures where the agency becomes free to create and draw on their own social culture, possibly differs by geographical location due to historical, industrial and locally-specific social pressures.

\section{Core peer groups}

Core peer groups subscribe to the ethos of a given subgroup in an organization, characterized in Frost et al. (1991) as an integrated group and exemplified from the research data diagram in Fig. 4.

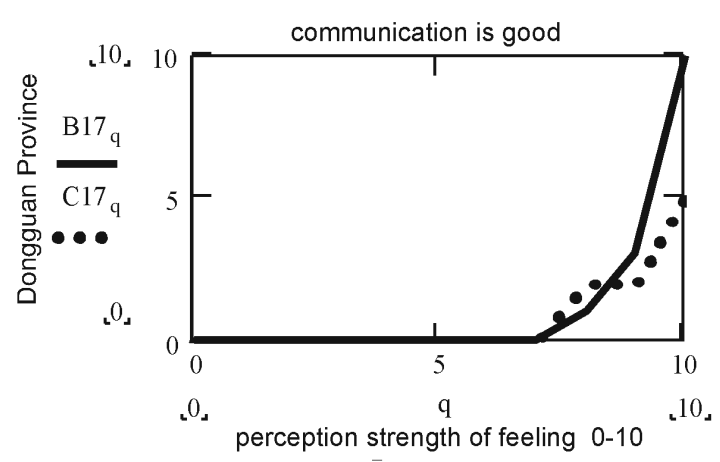

Fig. 4. Integrated perceptions (a single core group)

They are also, more fully, defined in the Merton (1967) proposals for reference groups and, from Fig. 5, reference individuals. The designations on the ordinates pertain to different factories. In Fig. 4, in response to a 
question about communication in the factory, most people rated performance between 8 to 10 ; this indicates strong agreement that communication is good and is classed as an 'integrated' response. In fact, for environmental matters it was benchmarked as poor.

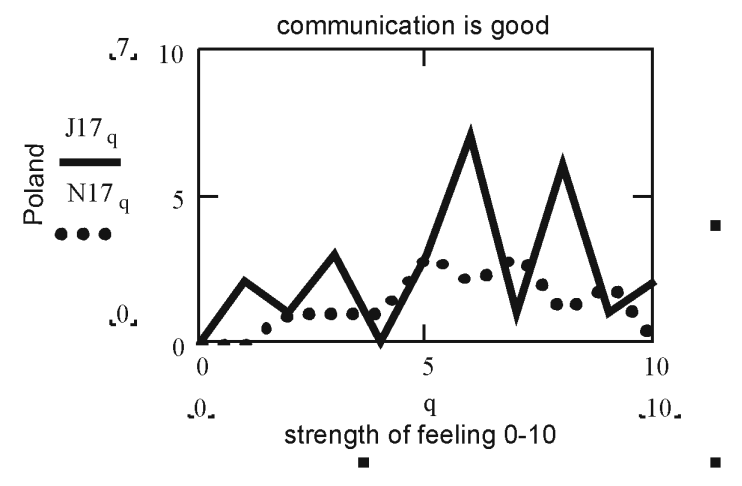

Fig. 5. Fragmented perceptions (no core group)

In Fig. 5, where the question related to the costs of environmental protection being below $10 \%$ of profits, the scores are spread across the abscissa and totally fragmented. This demonstrates that the communication originating (or not) from top management is poor.

Within most organizations there are managers who drift out of such (peer) groups to form a fringe population with no identifiable core group, Frost (1991) calls this a fragmented organization as exemplified in Fig. 5. The situation may also be rather more complex as there may be managers who subscribe in principle to core groups but who adopt different values (Alvesson 2002) dependent on beliefs which govern the behaviour for decision actions. These people root their decisions in subjectively derived cognitive models, which diverge among individuals (Heugens 2005) as in Fig. 5.

Craig and Lemon $(2004,2005)$ highlight how the distribution of these virtual groups or fragments were determined by establishing the perceptions of all the managers (203) in the study factories and plotting their strength of feeling responses to a twenty-item questionnaire based on environmental and production aspects. From this data it was possible to determine how distant their perceptions were from empirical reality. It is proposed that the phenomena which cause the gaps between empirical and perceptive realities are directly related to the degree of complexity extant in an organization.

\section{Discussion}

There was little difference between the Chinese and East European factories in the extent of fragmented responses although the patterns of these responses were nearly all different. This appears to confirm that people are complex and different one from another even if they subscribe individually, or perhaps unknowingly, to a framework or core peer group, the modes of conduct of which they may not always follow (Shibutani 1962).
Inherently, managers in a chain of command are involved in inter-actional role setting, but an individual in the chain can choose from an infinite number of role definitions with an infinite number of related job boundaries, but will need a re-definition if another manager's role changes (see also Turner 1962). An interesting facet in this context was the parachuting of new top managers, virtually overnight, into all of the Polish and some of the Chinese factories.

These new managers were unable to understand immediately, and sometimes long-term, what their interactional roles were, with the consequence that they could neither understand nor comprehend, at all, the pervading culture which they were sent to change, and were therefore at a significant disadvantage and at a severe risk of being parachuted out quite quickly (see also case note 6). As discussed in individual sections above, there is a multitude of complexities within which are topics that have been the subject of argument since the days of Sun $\mathrm{Zi}$ (circa 512BC) and Machiavelli (1506AD), and the possibility of new managers providing effective solutions to management and production problems, when incognizant of the factory culture, is rather remote.

One message from the survey and study is abundantly clear, each factory comprises different people with different perceptions, beliefs and values, and these different perceptions create framework groups which govern individual and factory behaviour and performance which reflect, in an obscure way, the complex processes in play in organizations.

\section{Conclusions}

Inter alia, the topics of empirical and perceived realities, socio-cultural and communication complexities have been discussed and the contingent complexities highlighted and these have been summarized within a practical factory context in the discussion above.

The use of the management framework models of Archer (1996) and Frost (1991) proved satisfactory in facilitating a discussion of the complexity surrounding why these do and do not work, as well as amply illustrating some of the problems of coherent management.

In the surveyed organizations it was established that the fragmented and variable operational cultures and subcultures interfered with the efficient management of those organizations dependent upon multiple variables occasioned by multiple and incoherent perspectives (of individuals) which were mostly a long way from empirical reality.

A significant mismatch was observed between what top management intended to happen in organization control and what actually materialized, this arising from different degrees of complexities on a topic, the subsequent uncertainty, and the ambiguity surrounding decisions on the environment.

It is concluded that, from the virtually infinite number of variables constituting successive options for differences, that there is both an unbounded rationality and an unbounded complexity to human affairs in organizations that even a Weberian iron cage bureaucracy would be unable to restrict. 


\section{References}

Alasuutari, P. 1995. Researching Culture - Qualitative Method. Sage. London.

Alexander, J. C. 1988. Durkheimian Sociology - Cultural studies. Cambridge UP.

Alvesson, M. 2002. Understanding Organizational Culture. Sage. London.

Archer, M. 1996. $2^{\text {nd }}$ edition. Culture and Agency - Culture in Social Theory. Cambridge UP

Badcock, C. 1991. Evolution and Individual Behaviour. Basil Blackwell Ltd., Oxford.

Bellah, R. N. 1973. Durkheim Morality and Society. University of Chicago Press.

Benveniste, G. 1981. Regulation and Planning, Boyd and Fraser. San Francisco.

Brehmer, B., et al. (Eds.). 1986. New Directions in Research in Decision Making. Elsevier, Amsterdam.

Burgess, E. W. 1962. Social Problems and Social Progress, in Rose, A. M. Human Behavior and Social Processes. Routledge and Kegan Paul, London, 381-400.

Cameron, K. S. \& Quinn, R. E. 1999. Diagnosing and Changing Organizational Culture. Addison Wesley, Longman, Harlow, UK

Chen, Z. \& Mayer, L. M. 1998. Digestive processes of the lugworm inhibited by copper from contaminated sediments, Environmental Toxicology and Chemistry 17(3): 99-108. Setac Press, USA.

doi:10.1897/1551-5028(1998)017<0433:DPOTLA> 2.3. $\mathrm{CO} ; 2$

Chen, Z.; Wakabayashi, M.; Takeuchi, N. 2004 A corporate study of organizational context factors for managerial career progress: focusing on Chinese State-owned, Sinoforeign and Japanese companies, The International Journal of Human Resource Management 15(4, 5): 750-774.

Cobley, P. (Ed.). 2001. Semiotics and Linguistics. Routledge, London.

Craig, J. H. S. 2001. Knowledge gaps in environmental decision making, the case of an Eastern European Manufacturing Sector. Open University Masters Thesis, Milton Keynes.

Craig, J. H. S. \& Lemon, M. 2008. Perceptions and reality in quality and environmental management systems: a research survey in China and Poland, The TQM Journal 20: 3. Emerald Group Publishing.

Dubin, R. 1962. Industrial Workers' Worlds - A study of the central life interests of industrial workers, in Rose, A. M. Human Behavior and Social Processes. Routledge and Kegan Paul, London, 247-266.

Faludi, A. 1987. A Decision Centered view of Environmental Planning. Pergamon Press, Oxford.

Fernandez, J. A. 2004. The gentleman's code of Confucious Leadership by Values, Organizational Dynamics 33(1): 21-31. Elsevier. doi:10.1016/j.orgdyn.2003.11.007

Frost, M., L. F.; Louis, M. R.; Lundberg, C. C.; Martin, J. (Eds.). 1991. Reframing organizational culture. London, UK, Sage.

Fu, P. P.; Peng, T. K.; Kennedy, J. C.; Yukl, G. 2004. Examining the preferences of influence tactics in Chinese societies, Organizational Dynamics 33(1): 32-46. Pergamon, London. doi:10.1016/j.orgdyn.2003.11.003

Glen, P. M.; LeBaron, C. D.; Mandelbaum, J. (Eds.). 2003. Studies in Language and Social Interaction. Lawrence Erlbaum Associates, New Jersey, USA.
Heugens, P. 2005. A neo-weberian theory of the firm, Journal of Organization Studies 26(4): 547-567. London, Sage. doi: $10.1177 / 0170840605051471$

Hodge, B. \& Coronado, G. 2007. Understanding change in organizations in a far-from-equilibrium world, $E$ : $C O$ 9(3): $3-15$.

Holmes, J. 2001. An Introduction to Socio-linguistics. $2^{\text {nd }}$ edition. Harlow, Pearson Education.

Hume on Knowledge 1739, in Noonan, H. W. 1999.

Likert Scale. 1932. Available from Internet: $<$ http://en.wikipedia.org/wiki/_Likert_scale>.

Lindsay, P. H. \& Norman, D. A. 1977. Human Information Processing. Academic Press, Elsevier Science Imprint, San Diego, USA.

Locke, John 1690-1764:1980. Second Treatise of Government, Hackett Publishing Company, Indianapolis, USA .

Locke, John 1877. Philosophical Works. Volumes $1 \& 2$. George Bell \& Sons, Covent Garden, London.

Lounsbury, M. and Carberry, E. J. 2005. April, from king to court jester, Organization Studies 26(4): 501-525. Sage, London. doi:10.1177/0170840605051486

Lubit, R. 2001. Tacit knowledge and knowledge management, Organizational Dynamics 29(3): 164-178. Pergamon, London. doi:10.1016/S0090-2616(01)00026-2

Machiavelli, N. 1961. The Prince. Penguin Books, London.

Mars, G. 1994. Cheats at Work. Dartmouth, Aldershot.

Merton, R. K. 1967. Social Theory and Social Structure. $11^{\text {th }}$ edition. Collier-MacMillan, London.

Morgan, G. 1989. Creative organization theory. Sage, USA.

Morgan, G. 1998. Images of Organization. Sage, USA.

Neilson, G. L.; Pasternack, B. A.; Van Nuys, K. E. 2005. The passive-aggressive organization, Harvard Business Review, Boston USA, 83-92.

Nobbs, J. et al. 1980. Sociology. $2^{\text {nd }}$ ed. MacMillan, London.

Noonan, H. W. 1999. Hume on Knowledge (1739). Routledge, London.

Patten, R. 1996.The new Management Reader. Routledge, London.

Perugini, M. \& Bagozzi, R. P. 2001. Theory of planned behaviour, British Journal of Social Psychology 40 Pt1.

Ramsey, J. 2004. Trope control: the costs and benefits of metaphor unreliability in the description of empirical phenomena, British Journal of Management 15(2): 143-155. Blackwell, Oxford UK. doi:10.1111/j.1467-8551.2004.00411.x

Rose, A. M. 1962. Human Behavior and Social Processes. Routledge and Kegan Paul, London.

Senge, P. M. 1990. The Fifth Discipline. Mackays, Chatham, Kent.

Shenghua, Y. 2008. Problems that lead to a failure in language communication, Asian Social Science 4(1): 106-109.

Shibutani, T. 1962. Reference Groups and Social Control, in Rose, A. M. Human Behavior and Social Processes. Routledge and Kegan Paul, London, 128-147.

Sperber, D 1996. Explaining Culture - A Naturalistic Approach. Blackwell, Oxford.

Stacey, R. 1992. Managing Chaos - dynamic business strategies. Saxon, Norman MA, USA.

Taylor, F. W. 1911. Scientific Management, Harper and Row. New York.

Tsui, A.; Wang, H.; Xin, K.; Zhang, L.; Fu, P. P. 2004. Variation of leadership styles among Chinese CEO's, Organiza- 
tional Dynamics 33(1): 5-20. Elsevier, Amsterdam. doi:10.1016/j.orgdyn.2003.11.002

Turner, R. H. 1962. Role Taking: Process versus Conformity, in Rose, A. M. Human Behavior and Social Processes. Routledge and Kegan Paul, London, 20-40.

Tyska, T. 1986. Information and evaluative processes in decision making: the role of familiarity, in New Directions in Research in Decision Making. Edited by Brehmer, B., et al. Elsevier, Amsterdam.

Wallace, J.; Hunt, J.; Richards, C. 1999. The relationship between organizational culture, organizational climate and managerial values, The International Journal of Public Sector Management 112(7): 548-564. doi:10.1108/09513559910305339

Weber, M. 1904-trs1948, translated by Gerth, H. H. and Mill, C. W. Essays in Sociology. Routledge \& Kegan Paul, London.

Wierzbicka, A. 1991. Cross-Cultural Pragmatics - the Semantics of Human Interaction. Mouton de Gruyter, Berlin. (OU book).

Zey, M. 1992. Decision Making - Alternatives to Rational Choice. London, UK, Sage.

\section{APLINKOS APSAUGOS VEIKSMINGUMO SUVOKIMO IR EMPIRINĖS REALYBĖS NEATITIKTIS: KINIJOS, LIETUVOS IR LENKIJOS İMONIŲ PAVYZDŽIAI}

\section{J. H. S. Craig, M. Lemon}

Santrauka

Imonès kultūra dažnai siejama su įmonės ekonominiu ir aplinkosauginiu veiksmingumu. Tai veda prie bendrų valdymo principų plètojimo ir taikymo, tačiau šie principai nepakankamai įvertina organizacijoje egzistuojančias daugialypes kultūras arba galimą atskirtį tarp darbuotojų suvokiamo aplinkosauginio veiksmingumo ir bandymų ji „objektyviai“ išmatuoti.

Straipsnyje pateiktas tyrimas susijęs su įsivaizduojamų ir objektyvių aplinkosauginio veiksmingumo priemonių palyginimu trylikoje Kinijos ir Rytų Europos sunkiosios pramonès įmonių. Rezultatai irode, kad ir horizontalusis, ir vertikalusis vadovavimo principas yra veikiami socialinių-kultūrinių ryšių šeimose, bendruomenėse ir darbo aplinkoje, todèl neišvengiamai lemia sudettingumą lyginant suvokiamą ir objektyvią aplinkos apsaugos realybę.

Reikšminiai žodžiai: sudètingumas, kultūra, realybė, kalba, hierarchija.

\section{ПОНИМАНИЕ ПРИРОДООХРАННОЙ ДЕЙСТВЕННОСТИ И СЛОЖНОСТЬ ЭМПИРИЧЕСКОЙ РЕАЛЬНОСТИ НА ПРИМЕРЕ ПРЕДПРИЯТИЙ ИЗ КИТАЯ, ЛИТВЫ И ПОЛЬШИ}

\section{Д. Г. С. Крэйг, М. Лемон}

Р ез ю м е

Культура предприятия зачастую оценивается на основании экономической и природоохранной действенности предприятия. Это способствует развитию и приспособлению общих принципов управления, однако эти принципы в недостаточной степени оценивают многогранную культуру, царящую в организации. Можно различить понимаемую работниками природоохранную действенность и попытки объективно ее измерить. Представленное в статье исследование направлено на сравнение своеобразно понимаемых и объективных природоохранных мер на тринадцати предприятиях тяжелой промышленности в Китае и Восточной Европе. Результаты показали, что как горизонтальный, так и вертикальный принципы руководства действенны в семьях, обществах и рабочей среде с социально-культурными связями, поэтому обусловлены сложностями, оказывающими воздействие на объективную природоохранную реальность.

Ключевые слова: сложность, культура, реальность, язык, иерархия.

\section{Dr John H.S. CRAIG PhD, CEng, CEnv, FIET, FCMI, FCQI, FIOM, MCIWM, drcraig@girac.co.uk}

\section{Girac (Consultants) Limited}

Dr John Craig has worked for many years in senior positions in design, production, management and marketing and, for ten years, was managing director of a world-renowned management systems certification body in the UK. In this latter function he has performed over 500 management and site-impact assessments and audits of large and small companies in the UK, Australia, China, Dubai, Germany, Greece, Hong Kong, Lithuania, Malaysia, Poland, Singapore, Switzerland, and Thailand for UKAS-accredited certification bodies. He also advises and implements management systems to meet the requirements of ISO9001, ISO14001, BS18001.

John has represented the UK at EU CENELEC Harmonization committees and has chaired the Operation Committee for testing methods together with the Harmonization marketing committee. Currently he represents the UK for the IEC/ISO committee on electro-magnetic compatibility.

His research and teaching areas are socio-cultural dynamics in organizations, design and sustainability, practical site environmental risk and impact assessment and the economic characterization and treatment of waste.

Dr Mark LEMON PhD, De Montfort Universitymlemon@dmu.ac.uk Social Scientist for Resource and Management. Dr Mark Lemon has been a social scientist in the Centre for Resource Management and Efficiency at Cranfield University and is now specializing in the sustainability of the built-environment at De Montfort University. His research interests cover a range of policy-relevant issues relating to the human-technical interface particularly as it affects sustainable development and the natural environment. Within this broad area he has focused on the factors that influence organizational 
74 J. H. S. Craig, M. Lemon. The complexities of perceived and empirical reality on environmental performance: industrial case...

culture, knowledge management and the way that multi-disciplinary and multi-agency teams define and respond to a wide range of environmental problems. Mark is involved in research and lecturing in the sustainability of the built-environment as well as:

- organizational culture, social enquiry and management systems

- complex systems perspectives for applied research

- qualitative research techniques and trans-disciplinarity

- environmental perception and participation

Mark has a particular interest in the characteristics of integrative research, the development of the trans-disciplinary (generic-cross-cutting) skills necessary to facilitate this and has published extensively in this area and is the author of Integrative Method and Environmental Change. He has undertaken and managed cross-disciplinary qualitative research within environmental projects for European, UK research agencies and commercial organizations, and has worked in Community Development projects and for several years in the construction industry. 